\title{
Immobilisation and leaching performance of lead-acid batteries smelting slag using natural and waste materials
}

\author{
Yusuf Tibet and Semra Çoruh \\ Department of Environmental Engineering, Ondokuz Mays University, 55200 Samsun, Turkiye \\ Received: 16/06/2017, Accepted: 12/10/2017, Available online: 25/10/2017 \\ *to whom all correspondence should be addressed: e-mail: semcoruh@omu.edu.tr
}

\begin{abstract}
The slag generated in the rotary furnaces is classified hazardous waste. In this regard, landfill disposal of lead smelting slag is not feasible since a few hundred tons are produced per year; leaching of heavy metals into ground water is of concern. The release of heavy metals into the environment has resulted in a number of environmental problems. The disposal of slag is becoming more expensive each year due to large land areas needed for its disposal. The best way to solve the disposal problem of waste materials is to decrease the quantity for disposal with utilization of waste materials in the industry. The toxicity of the waste is determined by leaching tests and depending on the characteristics of the waste the spent abrasive must be disposed of as solid or hazardous waste. The aim of this study is to investigate leaching characteristics of lead smelting slag according to leaching tests such as TCLP, and TS EN 12457-4 tests methods. In this study, mixed-level factorial design was applied to optimize process parameters for lead removal from lead smelting slag using natural (sepiolite, montmorillonite, illite and seashell) and waste material (red mud). The established model was then used as a predictor to achieve better understanding of the adsorption process and to obtain optimal settings of the experimental factors. The present study includes the safe disposal of lead smelting slag using natural and waste materials. Experimental results indicated that red mud and seashell can be used as environmentally friendly adsorbents that are capable of lead release from lead smelting slag.
\end{abstract}

Keywords: Lead smelting slag, lead leachability, immobilisation, natural and waste materials, factorial design

\section{Introduction}

Lead mining and metallurgy are significant branch of industry worldwide. Lead produced is fifth common metal production after steel, aluminium, copper and zinc by 1970s (Mining Specialization Commissions Report, 2001). The world production of lead from both primary and secondary resources was 3.9 Mt in 2009 (Ogundiran et al., 2013). The main application of lead is acceptable for batteries (Smaniotto et al., 2009). There are two types of batteries: 'primary batteries' and 'secondary batteries'. Lead-acid batteries are called secondary batteries or accumulators since they are rechargeable. The recovery of metals from metal scrap has the advantage that it is easier and far less energy dependent than the production of primary lead from ores. In Europe lead used for car batteries originated from secondary sources has now increased to more than $70 \%$ and in the USA to more than 90\% (Vest and Jantsch, 1999; Ogundiran et al., 2013; Kaksonen et al., 2016). Currently, lead is produced from pyrometallurgical recycling technologies in Turkey. Although no primary lead production occurs in Turkey, the country has a significant secondary lead market. In 2007 between 80,000 and 90,000 tonnes of scrap lead acid batteries were collected and recycled, representing 45,000 to 50,000 tonnes of secondary lead production. According to Kurt (Kurt, 2012), all of the lead - acid batteries are recycled and about $80 \%-85 \%$ of lead acid batteries comes from secondary smelting in Mutlu Corporation in Turkey. Lead acid batteries are recycled using a high-temperature, pyrometallurgical process. At the smelting step (900 $1200^{\circ} \mathrm{C}$ ), the lead compounds from the break are reduced to provide metallic lead, by smelting the battery paste with coke or other reducing agent rich in carbon and sodium hydroxide and sodium nitrate for the removal of other metals in the oxide form. Initially the lead presents in the sulphate form and after of the first stage of the reaction that occurs in the presence of the reducing agent (charcoal) in a temperature of about $650^{\circ} \mathrm{C}$. The lead is present in the form of sulphide where it is reduced in one second stage of the reaction in a temperature of about $1000{ }^{\circ} \mathrm{C}$. The properties established in the melting of the lead would also be improved, and less lead would be lost in the slag, with the use of $\mathrm{Na}_{2} \mathrm{CO}_{3}$ to work at a lower temperature and a better viscosity (Kreusch et al., 2007).

Approximately, 100 - $400 \mathrm{~kg}$ of slag for each ton of metallic lead produced is generated. It contains approximately $5 \%$ \%10 of lead compounds (Kreusch et al., 2007; Special waste statistics (2003-2009), 2011; Smaniotto et al., 2009). These slags are composed mainly of iron (approximately 60\%) and lead (approximately 6\%), and also trace elements such as $\mathrm{Cr}_{2} \mathrm{O}_{3}, \mathrm{CuS}, \mathrm{ZnO}, \mathrm{TiO}_{2}$. These residues cannot be disposed in conventional landfill due to the high lead content. All kinds of slags from secondary lead smelters are classified as 
hazardous waste in the European Waste Catalogue (European Waste Catalogue (EWC), 2000). The re-recycling technologies to treat hazardous waste are value recovery from the waste. If this is not technically and economically feasible, immobilisation is the next option. Waste immobilization techniques are the recent technologies proposed to prevent the free movement of contaminants in hazardous waste and surrounding media. Some natural and waste materials produced by the alkali activation of solid aluminosilicate precursors. These materials have been proposed as matrices for immobilization of various hazardous wastes. Toxic elements that are present in hazardous waste materials can be captured in such 3dimensional network structures. Although there are many researches on immobilisation technology, very few have considered in depth the leaching performance of lead smelting slags treated by different binders from different studies (Coz et al., 2009; Ogundiran et al. 2013; Kogbara, 2014;). This study presents a detailed leaching behavior of slag with and without natural and waste materials as immobilisation agents. These agents have high adsorption properties. Adsorption is a process where the atoms, ions or molecules of dissolved solids from liquid grips on the surface of solid; i.e. it is a process of mass transfer in which the dissolved solid from liquid gets deposited on the surface of solid because of physical or chemical interaction. The removal of heavy metals by using low cost adsorbent is found to be more encouraging in extended terms as there are several materials existing locally and profusely such as natural materials, agricultural wastes or industrial

Table 1. Chemical composition (wt. \%) of lead smelting slag, sepiolite, seashell, red mud, montmorillonite and illite

\begin{tabular}{|c|c|c|c|c|c|c|}
\hline & $\begin{array}{c}\text { Lead } \\
\text { smelting slag }\end{array}$ & Sepiolite & Seashell & Red mud & $\begin{array}{l}\text { Montmo- } \\
\text { rillonite }\end{array}$ & Illite \\
\hline $\mathrm{pH}$ & 9.91 & 8.83 & 9.77 & 10.16 & 8.62 & 9.03 \\
\hline $\mathrm{SiO}_{2}$ & 15.41 & 53.47 & 0.3 & 15.64 & 50.3 & 76.9 \\
\hline $\mathrm{Fe}_{2} \mathrm{O}_{3}$ & 40.77 & 0.16 & 0.1 & 36.24 & 6.0 & 1.5 \\
\hline $\mathrm{Al}_{2} \mathrm{O}_{3}$ & 3.01 & 0.19 & 0.2 & 20.10 & 13.7 & 12.0 \\
\hline $\mathrm{TiO}_{2}$ & 0.24 & - & $<0.1$ & 4.76 & 0.6 & 0.2 \\
\hline $\mathrm{CaO}$ & 2.08 & 0.71 & 38.5 & 2.68 & 7.1 & 0.8 \\
\hline $\mathrm{SO}_{3}$ & 0.61 & - & - & 0.06 & - & - \\
\hline $\mathrm{CO}_{2}$ & - & - & - & 2.93 & - & - \\
\hline $\mathrm{K}_{2} \mathrm{O}$ & 0.46 & - & $<0.1$ & - & 2.8 & 4.0 \\
\hline $\mathrm{MgO}$ & 0.42 & 23.55 & 0.1 & - & 2.3 & $<0.1$ \\
\hline $\mathrm{Na}_{2} \mathrm{O}$ & 5.35 & - & 0.4 & 9.99 & 0.6 & 1.2 \\
\hline $\mathrm{Mn}_{2} \mathrm{O}_{3}$ & 0.46 & - & - & - & - & - \\
\hline $\mathrm{P}_{2} \mathrm{O}_{5}$ & - & - & 0.1 & 0.02 & 0.2 & $<0.1$ \\
\hline LOI & 6.32 & - & - & 7.58 & - & - \\
\hline $\mathrm{PbO}+\mathrm{PbS}$ & 11.50 & - & - & - & - & - \\
\hline Others & 13.37 & 21.92 & 60.2 & - & 16.4 & 3.3 \\
\hline
\end{tabular}

\subsubsection{Sepiolite}

The sepiolite is used as natural material additives for leaching experiments. The sepiolite samples used for this study were obtained from Eskişehir in Turkey. The chemical composition of sepiolite is presented in Table 1 and it shows that sepiolite is primarily a mixture of $\mathrm{Si}$ and $\mathrm{Mg}$ oxides. The specific surface area (BET) of sepiolite is 82.35 $\mathrm{m}^{2} / \mathrm{g}$. The crystalline phase composition of the sepiolite in this study was characterized by SEM (SEM, Zeiss Supra 50VP) in Fig. 1 (b). by-products which can be utilized as low-cost adsorbents. These adsorbents should have high selectivity to facilitate quick separations, favorable transport and kinetic characteristics, thermal and chemical stability, mechanical strength, resistance to fouling, regeneration capacity and low solubility in the liquid in contact (Çoruh and Geyikçi, 2012; Tripathi and Ranjan, 2015).

The present study focuses on the safe disposal and leaching behavior of the lead smelting slag using natural and waste materials. Also, this study aims to optimize process parameters for lead removal from lead smelting slag using natural and waste materials.

\section{Materials and Methods}

\subsection{Materials}

\subsubsection{Lead smelting slag}

The chemical composition of lead smelting slag in experimental studies is summarized in Table 1 . The chemical composition of the major constituents listed in the lead smelting slag illustrates $\mathrm{Fe}_{2} \mathrm{O}_{3}(40.77 \%), \mathrm{SiO}_{2}$ (15.41\%), $\mathrm{PbO}+\mathrm{PbS}(11.50 \%)$ and some other oxides as $\mathrm{Al}_{2} \mathrm{O}_{3}, \mathrm{Na}_{2} \mathrm{O}$ and $\mathrm{CaO}$. The chemical composition of lead smelting slag refers to a multicomponent silicates system. The very high content of iron oxides indicates the potential of this slag to develop magnetic phases upon appropriate processing. The crystalline phase composition of the lead smelting slag in this study was characterized by SEM (SEM, Zeiss Supra 50VP) in Fig. 1 (a). 
study was characterized by SEM (SEM, Zeiss Supra 50VP) in Fig. 1 (c).

\subsubsection{Red mud}

The red mud sample was obtained from Seydişehir Aluminium Plant, Konya, Turkey. The chemical composition of red mud is presented in Table 1 and it shows that red mud is primarily a mixture of $\mathrm{Fe}, \mathrm{Al}, \mathrm{Si}$, and $\mathrm{Na}$ oxides. The specific surface area of red mud is $14.20 \mathrm{~m}^{2} / \mathrm{g}$. The crystalline phase composition of the red mud in this study was characterized by SEM (SEM, Zeiss Supra 50VP) in Fig. 1 (d).

\subsubsection{Montmorillonite}

The montmorillonite is used as natural material additives for leaching experiments. The montmorillonite samples used for this study were obtained from Artvin in Turkey.

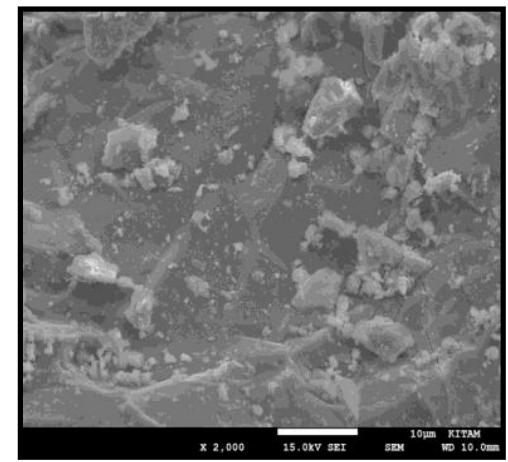

(a)

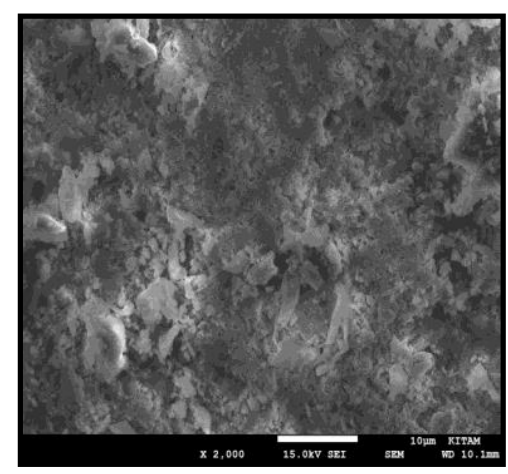

(c)

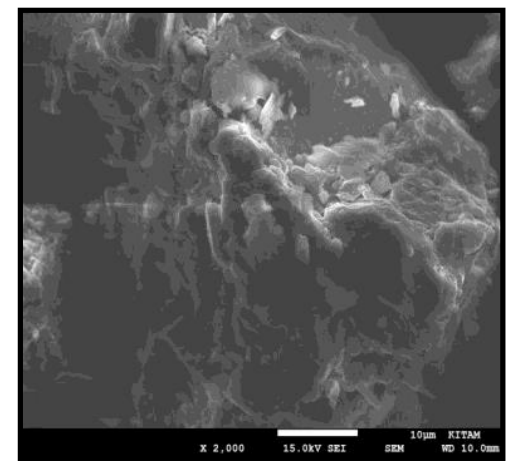

(e)
The chemical composition of montmorillonite is presented in Table 1 and it shows that montmorillonite is primarily a mixture of $\mathrm{Si}$, and $\mathrm{Al}$ oxides. The specific surface area of montmorillonite is around $46.90 \mathrm{~m}^{2} / \mathrm{g}$. The crystalline phase composition of the montmorillonite in this study was characterized by SEM (SEM, Zeiss Supra 50VP) in Fig. 1 (e).

\subsubsection{Illite}

The illite is used as natural material additives for leaching experiments. The illite samples used for this study were obtained from Samsun in Turkey. The specific surface area is $6.31 \mathrm{~m}^{2} / \mathrm{g}$. The chemical composition of illite is presented in Table 1. The total amount of $\mathrm{Si}$ and Al content is about $89 \%$. The crystalline phase composition of the illite in this study was characterized by SEM (SEM, Zeiss Supra 50VP) in Fig. 1 (f).

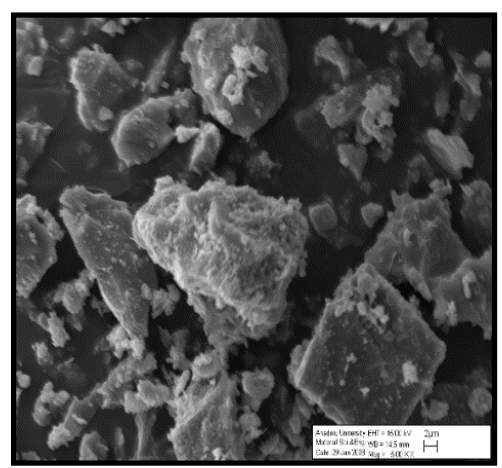

(b)

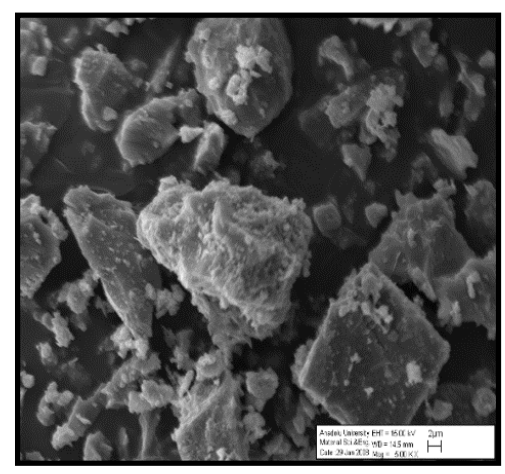

(d)

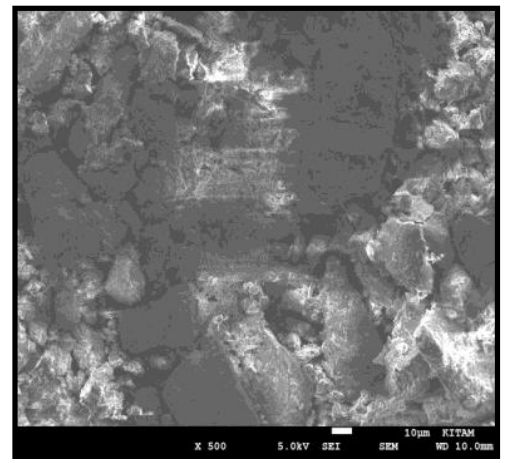

(f)

Figure 1. Scanning electron microscope (SEM) micrograph of the lead smelting slag, sepiolite, sea shell, red mud, montmorillonite and illite: (a) lead smelting slag; (b) sepiolite; (c) seashell; (d) red mud; (e) montmorillonite; (f) illite 


\subsection{Experimental procedure}

The leach tests are intended to measure the release of components from a solid waste sample in aqueous solution, e.g., acidic rainwater or landfill leachate, and can be used to simulate contaminant migration in groundwater. The TCLP is designed to determine the mobility of both organic and inorganic analyses present in liquid, solid as well as multiphasic samples. One of the requirements of this batch test is that it should be quick, simple to carry out and that the results should be reproducible. The TCLP analysis simulates landfill conditions. The TCLP test was performed as specified in the United States Environmental Protection Agency EPA method (USEPA, 1992). Toxicity Characteristic Leaching Procedure (TCLP) leaching test is often used to evaluate the immobilization efficiency. Acetic acid solution is used as extraction fluid in the TCLP test. The TCLP analysis determines which of the contaminants identified by the EPA are present in the leachate and their concentrations. For this purpose, the solid material is then extracted for at least 18 hours with sodium acetate/acetic acid buffer solution equal to 20 times its weight. The materials are placed in a tumbler to simulate the leaching action of water seeping through waste in the landfill. TCLP test is used for characterizing a waste as hazardous or non-hazardous, it is recognized to have little predictive value for long-term behavior (Cohen and Petrie, 2005; Demotica et al 2012).

TS EN 12457-4 test was performed in Turkish standards. Before doing this test, the solid matrices were crushed. The particle size of the crushed sample was kept less than $4 \mathrm{~mm}$ according to requirement of the TS EN 12457-4 procedure. A 10:1 liquid/solid (L/S, L/ $\mathrm{kg}$ ) ratio was employed, and the mixture was rotated for $24 \mathrm{~h}$ at $30 \mathrm{rpm}$ using a rotary agitation apparatus (Regulation of landfill of wastes, 2010).

Batch leaching tests were conducted to evaluate the leaching of pollutants in lead-acid batteries slag samples. The present study was undertaken to investigate the effect of the adsorbent amount, temperature, adsorbent type and leachate solution on the lead adsorption. These experiments were run in the batch reactors at different conditions such as adsorbent amount (10\%, 30\% and 50\%), temperature $\left(20\right.$ and $60{ }^{\circ} \mathrm{C}$ ), adsorbent type (sepiolite, sea shell, red mud, montmorillonite and illite) and leachate solution (TCLP and TS EN 12457-4). The samples were mixed at predetermined periods at a temperature of $20^{\circ} \mathrm{C}$ in a shaker at $150 \mathrm{rpm}$. The $\mathrm{pH}$ of the leaching solutions for all tests were measured and thereafter acidified with $\mathrm{HNO}_{3}$ to decrease the $\mathrm{pH}$ to below 2 prior to instrumental analysis. In selected experiments, the solution was filtered by using a membrane filter and analyzed for residual metal content AAS (Atomic Absorption Spectrophotometry, UNICAM 929 Model).

\subsection{Factorial designs}

Factorial design is the system which is based on all trial combinations formed by levels of factors. Factorial design is not a designation but an experiment which tests whether there is a significant difference between trials. The method is used for simultaneously studying main effects and interactions of two or more factors. 2 level or 3 level experimental designs are special designs and named according to level number. Since factor number is represented as $k$, these systems are identified as $2^{\mathrm{k}}$ or $3^{\mathrm{k}}$ factorial orders.

Experimental combination number is equal to the multiplication of factor level numbers. In experiments for lead removal, 4 factors have been used: adsorbent type, leachate solution applied, adsorbent amount and temperature. Adsorbent type is composed of 5 levels, leachate solution is composed of 2 levels, adsorbent amount is composed of 3 levels and temperature is composed of 2 levels. The trial number of factors shown in Table 2 is $5 \times 2 \times 3 \times 2=60$; and each experiment has been conducted iteratively. Outcomes of the experiment have been evaluated by full factorial design method using Minitab (Version 17) statistical software (Montgomery et al., 2001; Ai et al., 2006; Erbaş and Semra, 2006; Zhao and Chen, 2012a, 2012b; Şenoğlu and Acıtaş, 2014; Yin and Zhou, 2015).

Table 2. The Levels of experimental factors

\begin{tabular}{|c|c|c|c|c|}
\hline & \multicolumn{4}{|c|}{ FACTORS } \\
\hline & $\begin{array}{l}\text { Adsorbent Type } \\
\text { (A) }\end{array}$ & $\begin{array}{l}\text { Leachate Solution } \\
\text { (B) }\end{array}$ & $\begin{array}{l}\text { Adsorbent } \\
\text { amount (\%) } \\
\text { (C) }\end{array}$ & $\begin{array}{c}\text { Temperature }\left({ }^{\circ} \mathrm{C}\right) \\
\text { (D) }\end{array}$ \\
\hline \multirow{5}{*}{ 岂 } & Sepiolite & TS EN 12457-4 & 10 & 20 \\
\hline & Seashell & TCLP & 30 & 60 \\
\hline & Red Mud & & 50 & \\
\hline & Montmorillonite & & & \\
\hline & Illite & & & \\
\hline
\end{tabular}

\section{Result and Discussion}

\subsection{Effect of leachate solution on lead release from lead smelting slag}

Lead release from lead smelting slag as a function of leachate solution is presented in Fig. 2. As can be seen from the Fig.2, lead releases for TS EN 12457-4 test solution at different temperatures $\left(20\right.$ and $60{ }^{\circ} \mathrm{C}$ ) were obtained as
17.74 and $18.05 \mathrm{mg} / \mathrm{L}$, respectively. The highest lead release by TCLP methods was observed. TCLP lead releases for 20 and $60{ }^{\circ} \mathrm{C}$ were found to be 525.60 and $431.20 \mathrm{mg} / \mathrm{L}$, respectively. It was also reported that the metal concentrations in the TCLP leachate were significantly higher than the TS EN 12457-4 leachate. This is due to the $\mathrm{pH}$ difference between the applied leachate fluids and also between the final leachate $\mathrm{PH}_{\mathrm{s}}$. The $\mathrm{pH}$ of the TCLP leachate 
fluid was around 4.93-5.91, but that of TS EN 12457-4 was around 9.50-10.60. Therefore, the TCLP conditions for the lead smelting slag samples than TS EN 12457-4. Also, the TCLP leach test results in slag in solid breakdown both due to attack by the acetic acid and, to a lesser degree, attrition. The result of breakdown increases exposed surface area and also reduces the intra-particle diffusion path.

This result can be explained by the chemical nature of the leaching solution, the affinity of metal(s) with the leaching ion, and the competing redox conditions in the solution (Singh and Pant, 2006; Demotica et al., 2012; Kumar et al.,
2014; Yadav and Yadav, 2014; Yu et al., 2015,). The leaching tests showed the lead release from lead smelting slag exceed the limits of Turkish and EPA standards. Leaching concentration for lead in Turkish and EPA standards are $1 \mathrm{mg} / \mathrm{L}$ and $5 \mathrm{mg} / \mathrm{L}$, respectively.

The lead smelting slag samples were subjected TCLP and TS-EN 12457-4 tests to determine the leachability characteristics and adsorption ability for heavy metals in the slag using natural (sepiolite, montmorillonite, illite and sea shell) and waste material (red mud). These results are summarized in Table 3.

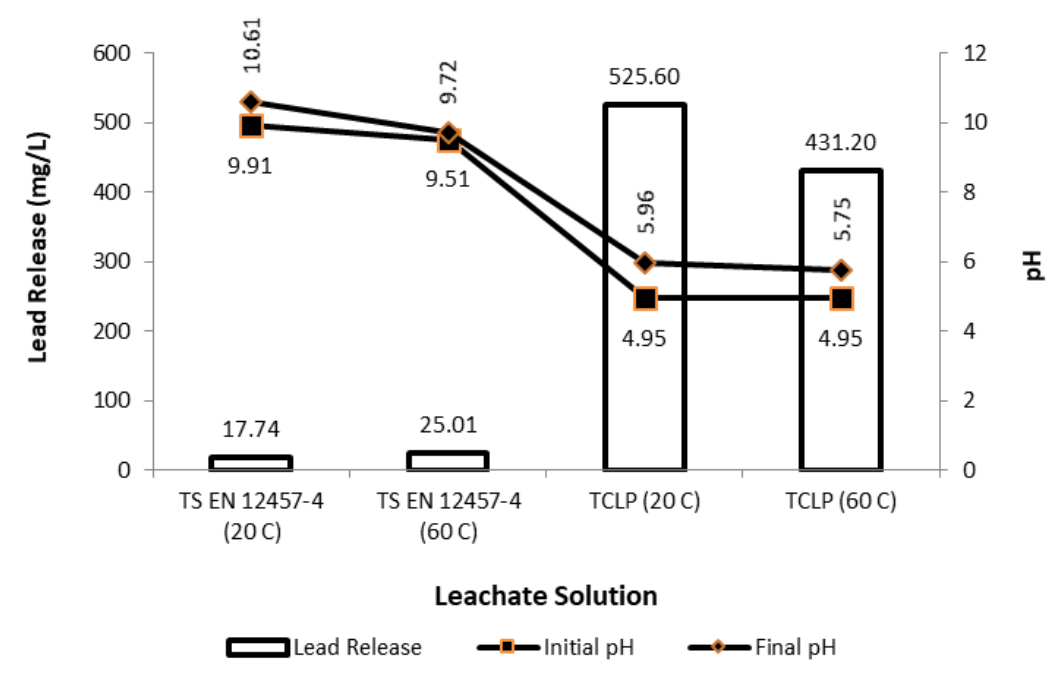

Figure 2. Effects of leachate solution for lead release from lead smelting slag

Table 3. Lead removal efficiency (\%)

\begin{tabular}{|c|c|c|c|c|c|c|c|}
\hline \multicolumn{2}{|c|}{ Adsorbent Amount } & \multicolumn{2}{|l|}{$10 \%$} & \multicolumn{2}{|l|}{$30 \%$} & \multicolumn{2}{|l|}{$50 \%$} \\
\hline Adsorbent Type & Temperature & TS EN 12457-4 & TCLP & TS EN 12457-4 & TCLP & TS EN 12457-4 & TCLP \\
\hline \multirow{2}{*}{ Sepiolite } & $20^{\circ} \mathrm{C}$ & 41.68 & 9.02 & 95.55 & 18.70 & 99.28 & 25.39 \\
\hline & $60^{\circ} \mathrm{C}$ & 96.76 & 98.81 & 98.04 & 99.49 & 97.28 & 99.16 \\
\hline \multirow{2}{*}{ Seashell } & $20^{\circ} \mathrm{C}$ & 27.40 & 99.63 & 58.74 & 99.70 & 91.04 & 99.78 \\
\hline & $60^{\circ} \mathrm{C}$ & 96.84 & 99.75 & 97.16 & 99.46 & 97.84 & 99.32 \\
\hline \multirow{2}{*}{ Red Mud } & $20^{\circ} \mathrm{C}$ & 35.68 & 12.58 & 86.98 & 72.85 & 97.13 & 96.12 \\
\hline & $60^{\circ} \mathrm{C}$ & 17.03 & 12.24 & 72.49 & 94.61 & 53.46 & 97.43 \\
\hline \multirow{2}{*}{ Montmorillonite } & $20^{\circ} \mathrm{C}$ & 24.46 & 69.58 & 66.23 & 97.67 & 94.02 & 99.11 \\
\hline & $60^{\circ} \mathrm{C}$ & 97.08 & 0.26 & 98.43 & 4.85 & 99.80 & 41.19 \\
\hline \multirow{2}{*}{ Illite } & $20^{\circ} \mathrm{C}$ & 0.17 & 8.43 & 9.90 & 20.11 & 9.53 & 32.91 \\
\hline & $60^{\circ} \mathrm{C}$ & 96.24 & 0.26 & 97.28 & 0.39 & 96.56 & 17.86 \\
\hline
\end{tabular}

\subsection{Effect of particle size on lead release from lead smelting slag}

Lead leaching as a function of particle size is presented in Fig. 3. The particle size during all study was chosen as $0.35+0.50 \mathrm{~mm}$. An increase in lead ions in the TS-EN 124574 leachate as particle size deceases was observed. Lead leachate concentrations for $+1.19-2.0 \mathrm{~mm}$ and $0.35+0.50$ $\mathrm{mm}$ particle sizes were found to be 7.24 and $17.74 \mathrm{mg} / \mathrm{L}$.

Fig. 4 presents the effects of particle size on lead release by TCLP leachate solution from lead smelting slag as a function of particle size. As can be seen from the Fig. 4 as the particle size decreased, metal release increased. The highest lead release by TCLP methods was observed as $525.6 \mathrm{mg} / \mathrm{L}$ for $0.35+0.50 \mathrm{~mm}$ particle size. The result of TCLP test was higher than TS-EN 12457-4 test methods. Apparently the metal concentrations obtained by the TCLP method were rather high, which is consistent with the general principles that TCLP always presents the maximum leachate concentration for environmental samples (Al-Abed et al. 2006). These results demonstrate that the $\mathrm{pH}$ value of the extraction medium, liquid:solid ratio and extraction time are predominant parameters affecting leachability. 


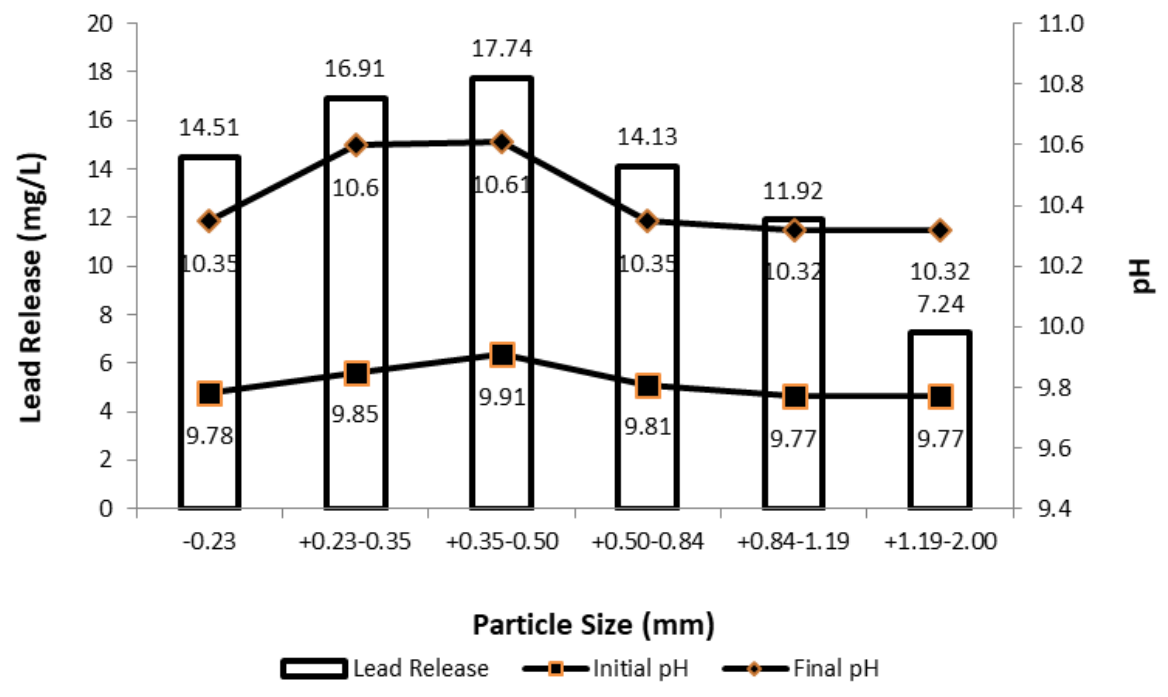

Figure 3. Effects of particle size on lead release by TS-EN 12457-4 leachate solution from lead smelting slag

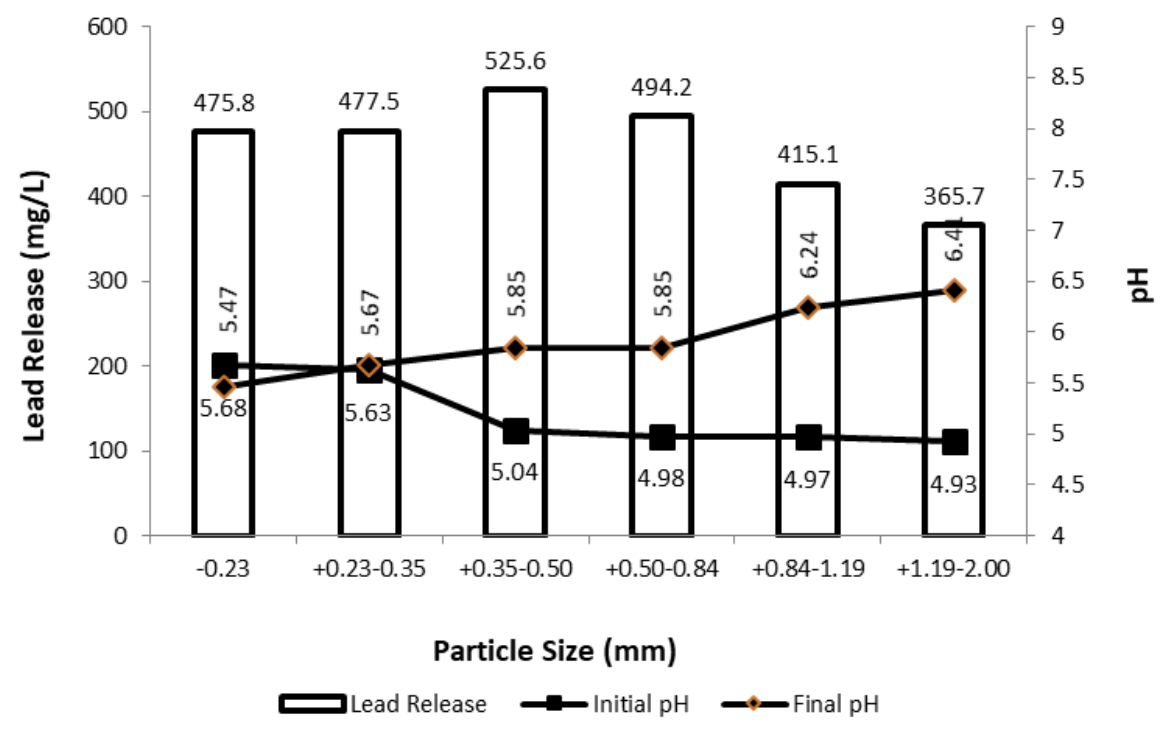

Figure 4. Effects of particle size on lead release by TCLP leachate solution from lead smelting slag

\subsection{Factorial design evaluation}

The analysis of variance show that the main effects of Adsorbent Type $(A)$, Leachate Solution $(B)$, Adsorbent Amount $(C)$, and Temperature $(D)$ and the interactions $A B$, $A C, A D, B C, B D, C D, A B C, A B D, A C D$ and $A B C D$ are significant at the $5 \%$ level. In Table 3, the column labeled " $P$ " presents the $P$ statistic for testing the null hypothesis that states that the main effects and the 2-way, 3-way and 4-way interactions are equal to zero, respectively. The column labeled " $P$ " presents the $P$-value for the $F$ test. The slight $P$ values $(<0.05)$ mean that all of the main effects and interactions are effective at the $5 \%$ significance level.

These results argued good agreements between the predicted and experimental values of lead removal efficiency. The fit models submitted square correlation coefficient $\left(R^{2}\right)$ of 0.9994 was in good agreement.

In F-Value of Table 4, it can be observed that the adsorbent type (23.08\%) has most significant effect on lead removal of lead smelting slag compared to the other parameters. The influence values of the parameters follows as interaction of adsorbent type*leachate solution*temperature, interaction of adsorbent type*temperature and adsorbent amount with the ratios of $20.88 \%, 11.6 \%$ and 10.95 , respectively. The representation of the main effect and the interaction factors most affecting the response is shown in Table 5.

The sufficiency of the models was also appraised by the residuals. Residual is the difference between the observed and the predicted response value. Residuals are thought as elements of variation unexplained by the fitted model and then it is expected that they occur according to a normal distribution. The observed residuals are plotted against the expected values, given by a normal distribution in Fig.5. Trends seen in Fig.5 reveal reasonably well behaved residuals. In this graphics, the residuals seem to be randomly scattered. 
Table 4. Analysis of variance for removal efficiency

\begin{tabular}{|c|c|c|c|c|c|}
\hline Source & D.F. & Seq SS & Adj MS & F-Value & $\mathrm{P}$ \\
\hline Model & 59 & 177132 & 3002.2 & 1597.16 & 0.000 \\
\hline Linear & 8 & 73909 & 9238.6 & 4914.81 & 0.000 \\
\hline Adsorbent Type & 4 & 40904 & 10226.1 & 5440.15 & 0.000 \\
\hline Leachate Solution & 1 & 5976 & 5976.1 & 3179.24 & 0.000 \\
\hline Adsorbent Amount (\%) & 2 & 19412 & 9706.0 & 5163.49 & 0.000 \\
\hline Temperature (C) & 1 & 7616 & 7616.1 & 4051.69 & 0.000 \\
\hline 2-Way Interactions & 21 & 57897 & 2757.0 & 1466.69 & 0.000 \\
\hline Adsorbent Type * Leachate Solution & 4 & 15615 & 3903.7 & 2076.74 & 0.000 \\
\hline Adsorbent Type * Adsorbent Amount & 8 & 11323 & 1415.4 & 752.99 & 0.000 \\
\hline Adsorbent Type * Temperature & 4 & 20658 & 5164.6 & 2747.49 & 0.000 \\
\hline Leachate Solution * Adsorbent Amount & 2 & 153 & 76.6 & 40.74 & 0.000 \\
\hline Leachate Solution * Temperature & 1 & 7395 & 7394.7 & 3933.89 & 0.000 \\
\hline Adsorbent Amount * Temperature & 2 & 2752 & 1376.2 & 732.15 & 0.000 \\
\hline 3-Way Interactions & 22 & 44088 & 2004.0 & 1066.11 & 0.000 \\
\hline Adsorbent Type * Leachate Solution * Adsorbent Amount & 8 & 3148 & 393.5 & 209.32 & 0.000 \\
\hline Adsorbent Type * Leachate Solution * Temperature & 4 & 37004 & 9251.1 & 4921.47 & 0.000 \\
\hline Adsorbent Type * Adsorbent Amount * Temperature & 2 & 1727 & 215.9 & 114.84 & 0.000 \\
\hline Leachate Solution * Adsorbent Amount * Temperature & 2 & 2209 & 1104.5 & 587.60 & 0.000 \\
\hline 4-Way Interactions & 8 & 1238 & 154.8 & 82.35 & 0.000 \\
\hline $\begin{array}{l}\text { Adsorbent Type * Leachate Solution * Adsorbent Amount * } \\
\text { Temperature }\end{array}$ & 8 & 1238 & 154.8 & 82.35 & 0.000 \\
\hline Error & 60 & 113 & 1.9 & & \\
\hline Total & 119 & 177245 & & & \\
\hline$R^{2}(\operatorname{adj})=99.87 \% \quad R^{2}($ pred $)$ & $9.75 \%$ & & & & \\
\hline
\end{tabular}

Table 5. Effect of factors

\begin{tabular}{cc}
\hline Source & Contribution (\%) \\
\hline Model & $\mathbf{9 9 . 9 4}$ \\
\hline Linear & $\mathbf{4 1 . 7 0}$ \\
\hline Adsorbent Type & 23.08 \\
\hline Leachate Solution & 3.37 \\
\hline Adsorbent Amount & 10.95 \\
\hline Temperature & 4.30 \\
\hline 2-Way Interactions & $\mathbf{3 2 . 6 6}$ \\
\hline Adsorbent Type*Leachate Solution & 8.81 \\
\hline Adsorbent Type*Adsorbent Amount & 6.39 \\
\hline Adsorbent Type*Temperature & 11.66 \\
\hline Leachate Solution*Adsorbent Amount & 0.09 \\
\hline Leachate Solution*Temperature & 4.17 \\
\hline Adsorbent Amount *Temperature & 1.55 \\
\hline 3-Way Interactions & $\mathbf{2 4 . 8 7}$ \\
\hline Adsorbent Type*Leachate Solution*Adsorbent Amount & 1.78 \\
\hline Adsorbent Type*Leachate Solution*Temperature & 20.88 \\
\hline Adsorbent Type*Adsorbent Amount *Temperature & 0.97 \\
\hline Leachate Solution*Adsorbent Amount *Temperature & 1.25 \\
\hline 4-Way Interactions & $\mathbf{0 . 7 0}$ \\
\hline Adsorbent Type*Leachate Solution*Adsorbent Amount *Temperature & 0.70 \\
\hline Error & 0.06 \\
\hline Total & 100.00 \\
\hline
\end{tabular}




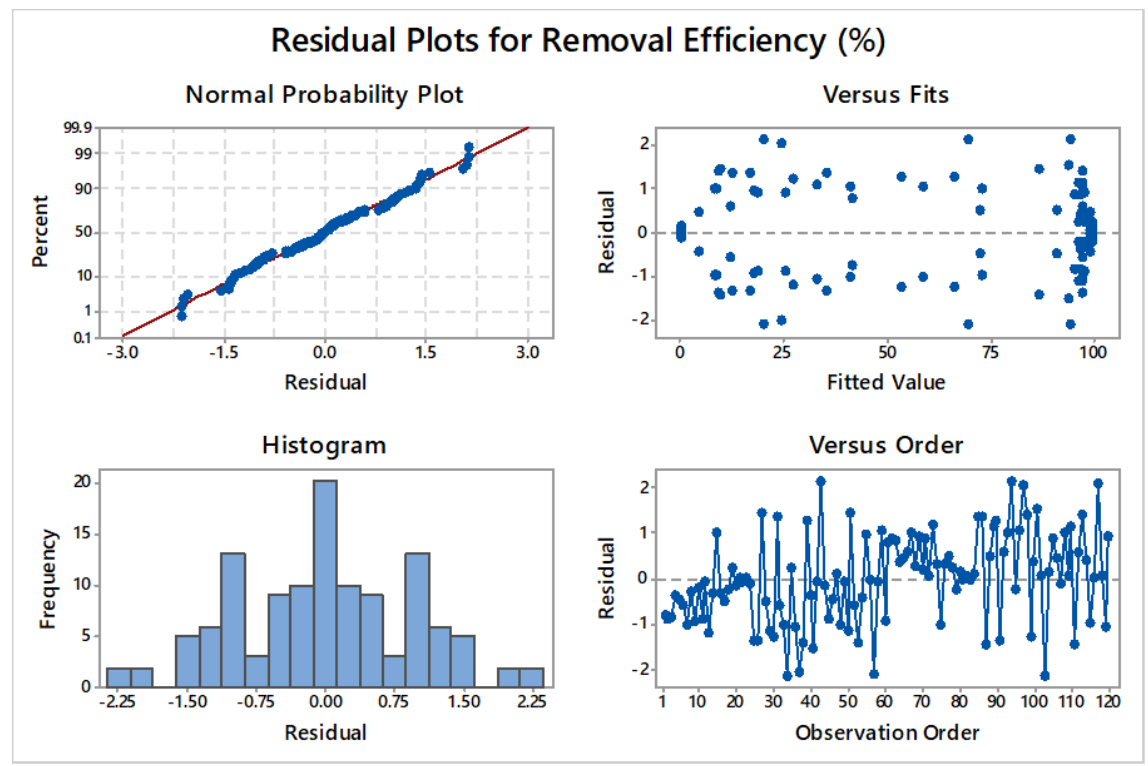

Figure 5. Residual plots for lead removal efficiency from lead smelting slag

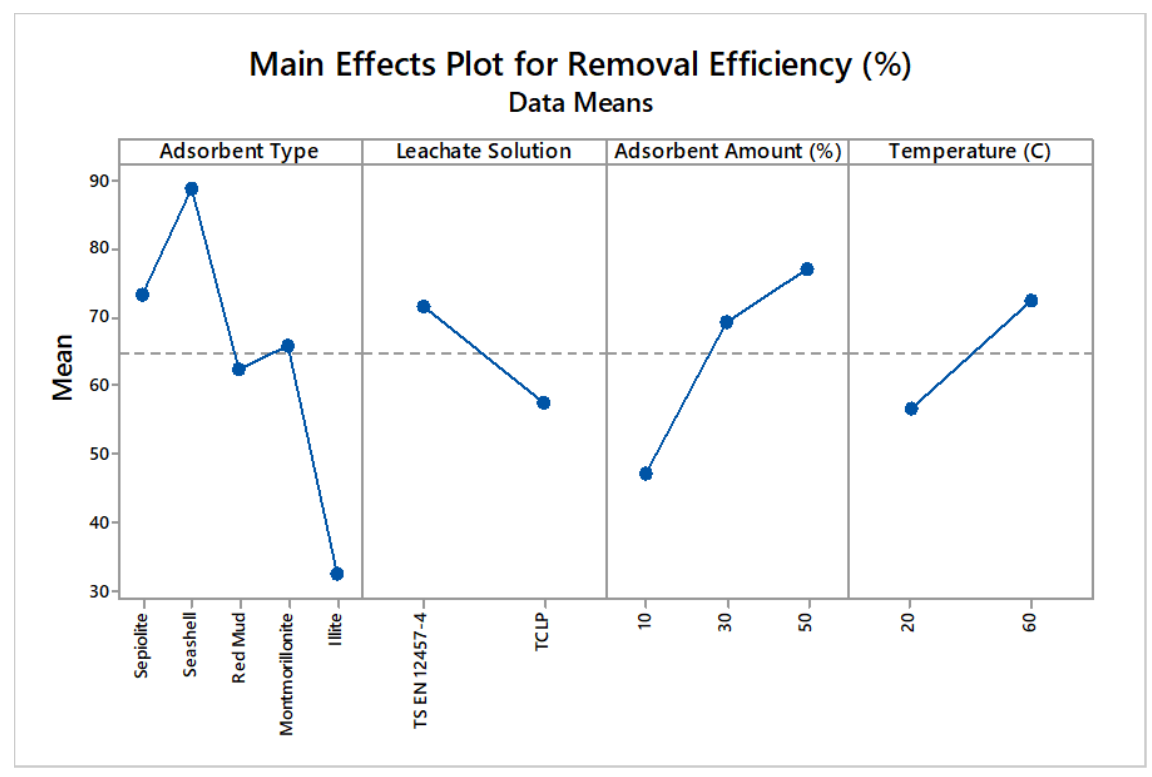

Figure 6. Main effects plot for lead removal efficiency from lead smelting slag

Fig 6 shows a main effects plot, offering the effect of each variable on the response factor. This type of figuration shows the contribution to the response factor of changing one of the influential variables. When the effect of a factor is negative, removal efficiency decreases as the factor changes from low to high levels. In contrast if effect is positive, an increase in removal efficiency occurs for high level of the same factor. If the magnitude of the main effect is small, the slope would be close to zero.

Adsorbent type is the most influential variables for lead removal. According to the TCLP method, the lead removal efficiencies from lead smelting slag with $10 \%, 30 \%$ and $50 \%$ seashell material for $20{ }^{\circ} \mathrm{C}$ temperature were obtained as $99.63 \%, 99.70 \%$ and $99.78 \%$, respectively. However, in the same temperature, according to the TS-EN 12457 testing procedure, the lead removal efficiencies from lead smelting slag including those percentages of seashell material were established as $27.40 \%, 58.74 \%$ and $91.04 \%$, respectively. Furthermore, the lead removal efficiencies from lead smelting slag with $10 \%, 30 \%$ and $50 \%$ seashell material for $60{ }^{\circ} \mathrm{C}$ temperature were found as $99.75 \%$, 99.46\% and $99.32 \%$, respectively, when performing TCLP method, while those values were $96.84 \%, 97.16 \%$ and $97.84 \%$, respectively, by utilizing TS-EN 12457 testing procedure. Increasing the adsorbent amount results in an increase in the lead removal efficiency. The seashells are composed of a mixture of calcium carbonate, protein and chitin, with relatively small amounts of lipid, phosphate and pigment. Several authors have found that comminuted, ground or powdered shell material has very high heavy metal adsorption capacities. An alternative mechanism to adsorption is that metal uptake occurs through ion exchange and conversion of calcium and magnesium carbonates to mixed-metal carbonates in the inorganic fraction of the shell structure. Kim and Park (Kim and Park, 2001) confirmed that $\mathrm{K}+, \mathrm{Na}+, \mathrm{Mg} 2+$ and $\mathrm{Ca} 2+$ were released from crab shell in association with $\mathrm{Pb} 2+$ 
uptake to the crab shell suggesting that the mechanism of uptake was through ion exchange and the formation of mixed-metal carbonates (Craggs et al., 2006). Sepiolite, montmorillonite and red mud materials indicate similar results for lead removal from lead smelting slag. Silanol groups $(\mathrm{SiOH})$ to especially sepiolite are present at the border of each block in the external of surface of silicate and act as neutral sites for lead adsorption (Vaclavikova et al., 2005; Güneren, 2010; Eren and Gumus, 2011; Ozdes et al., 2011; Djukić et al., 2013; Sahu et al., 2013; Araç, 2014; Kumar et al., 2014).

The interaction plot shows the possible interaction between the mean responses of the factors under assessment. An interaction plot circumstances the impact that the act of changing the settings of one factor has on another factor. Graphically, two parallel lines of factors indicate no interaction between them; however nonparallel lines suggest that the two factors interact together. The interaction plot in Fig.7 confirms all of the interactions are significant. Fig. 8 (a) indicates the removal efficiency dependence on adsorbent type and adsorbent amount. For lead removal efficiency, a significant increase in the amount adsorbent at equilibrium with the increase of adsorbent amount from $10 \%$ to $50 \%$ can be observed. This expected observation is a result of the increase in the specific surface on the adsorbent. These results demonstrated that the presence of aragonite and calcite phases in seashell is effectively able to remove lead metal ions. The increase in the removal of lead metal ion caused by the seashell amendment could be due to the higher $\mathrm{pH}$ value in the equilibrium solution promoted by the seashell. The higher $\mathrm{pH}$ value would cause an increase in the hydroxylation of the metals, and even its precipitation at high doses, as well as an increase in the negative charge of the variable charge components of the slag, thus favoring the adsorption of metals present in cationic form. Du at al. (Du et al., 2011) and Sipos et al. (Sipos et al., 2008), investigating the adsorption of $\mathrm{Cd}, \mathrm{Pb}$ and $\mathrm{Zn}$ on soil mineral phases found that alkaline conditions due to the carbonate content of soils resulted both in increased adsorption on the mineral particles for $\mathrm{Cu}$, and in enhanced role of precipitation for all the studied metals, and they indicate that in this case not the adsorption but the precipitation is the most important immobilization process (Filiz, 2007; Ghasemi et al., 2013; Wu et al., 2014).

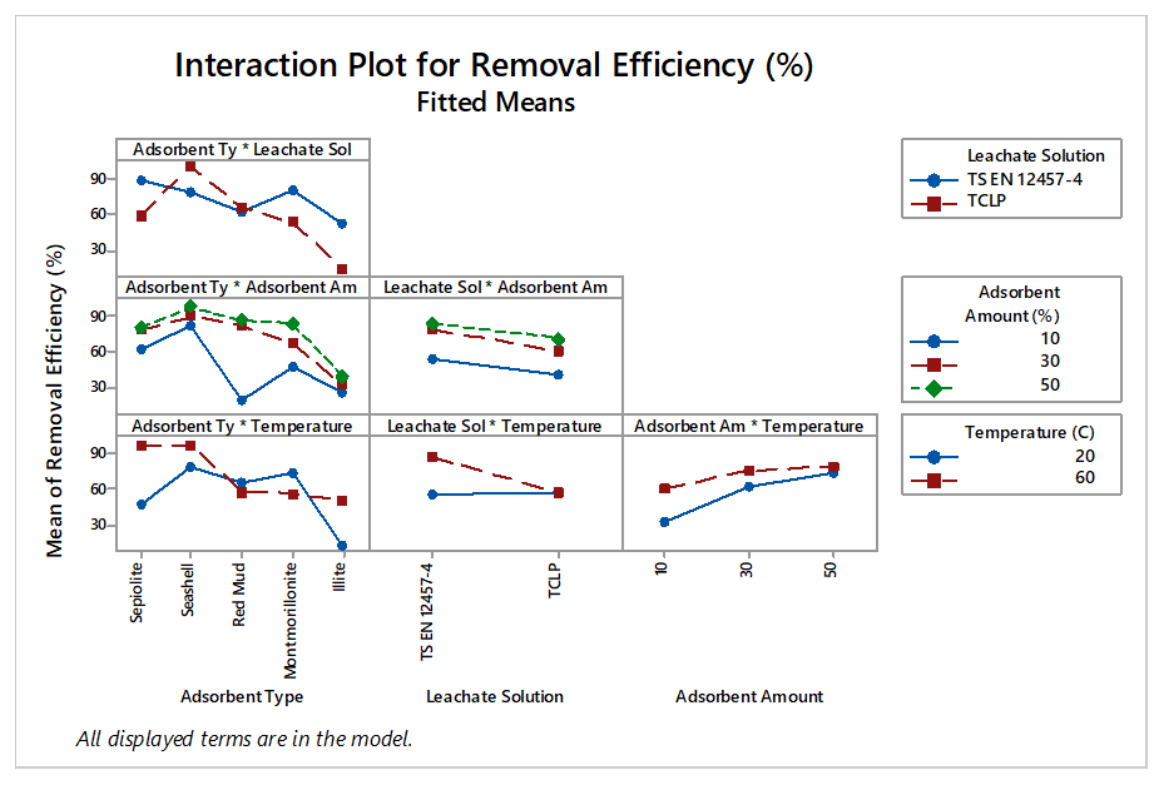

Figure 7. Interaction effects plot for lead removal efficiency

Fig. 8 (b) and (d) shows that an increase in temperature between 20 and $60^{\circ} \mathrm{C}$ causes a linear slight increase in the lead removal efficiency for adsorbent amount and leachate solution. Fig 8. (c) illustrates the effect on lead removal of temperature. The efficiency of lead removal changes according to adsorbent type in temperature between 20 and $60{ }^{\circ} \mathrm{C}$. While the seashell shows high removal efficiency, illite material shows lower removal efficiency.

\section{Conclusions}

In this study, the leaching characteristics of the lead smelting slag originating from lead recovery of exhausted batteries were investigated. Adsorptions modelling for lead removal in experiments, 4 factors have been used: adsorbent type, leachate solution applied, adsorbent amount and temperature. Adsorbent type is composed of 5 levels, leachate solution (toxicity test) is composed of 2 levels, adsorbent amount is composed of 3 levels and temperature is composed of 2 levels. Toxicity tests, including TCLP and TS EN 12457-4 tests methods, were applied to lead smelting slag. The TCLP and TS EN 12457-4 test results show that decrease in particle size leads to an increase in lead ion releases. The results of laboratory leaching tests demonstrate that adding of sepiolite, montmorillonite, illite, sea shell and red mud to the lead smelting slag drastically reduces the lead metal content in the leachate and the seashell and red mud performs better than the other materials. 


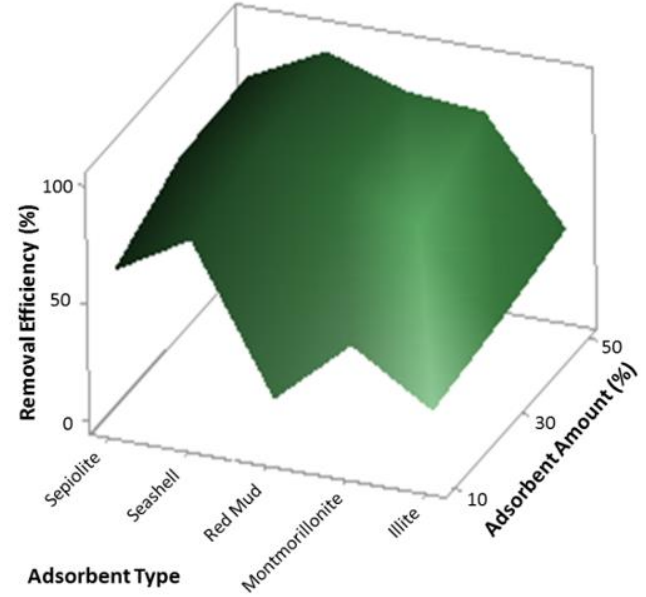

(a)

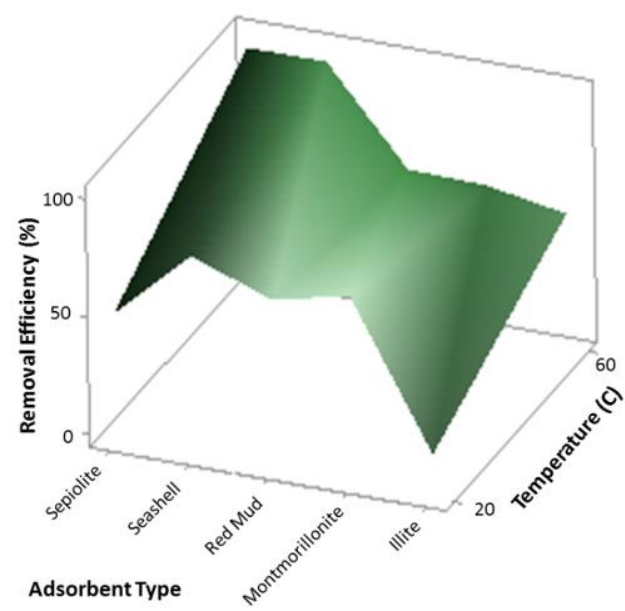

(c)

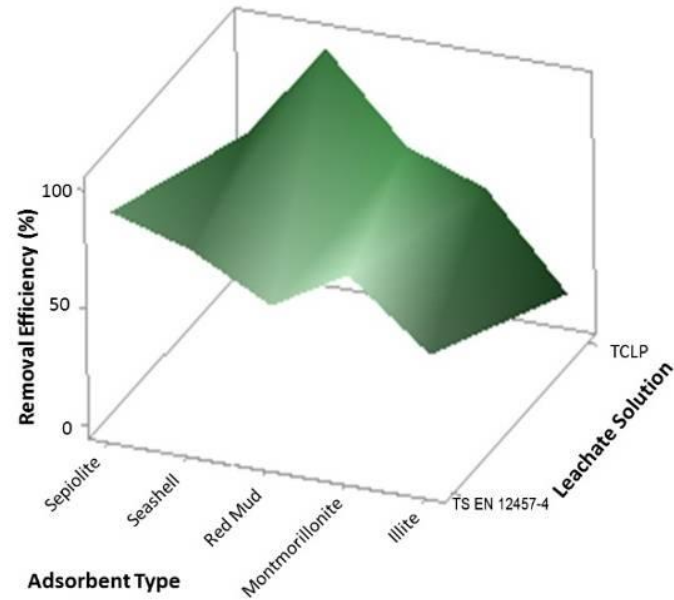

(e)

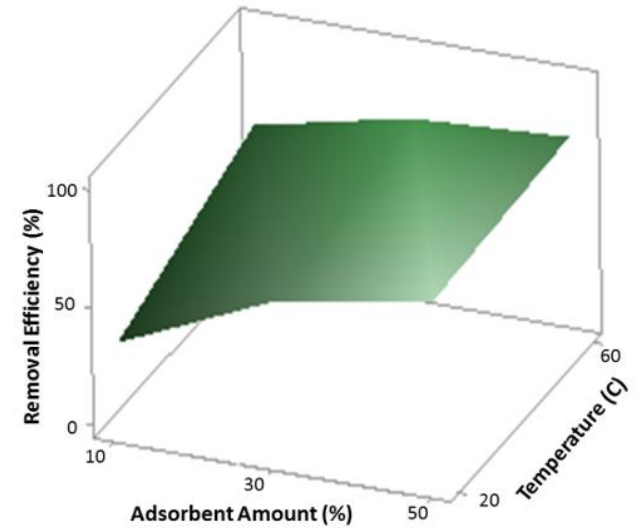

(b)

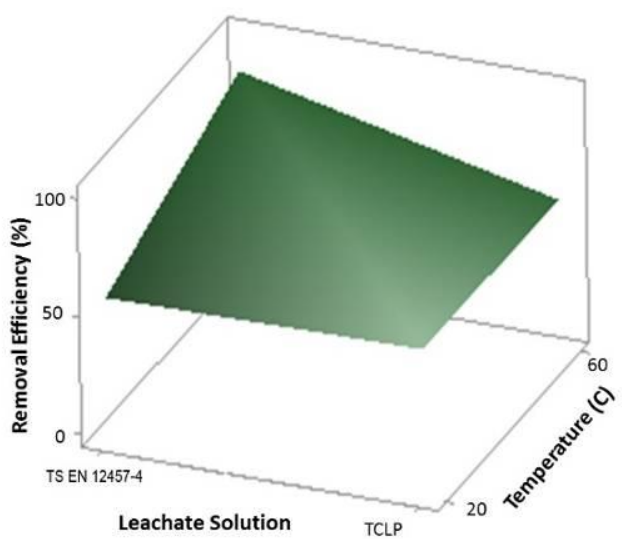

(d)

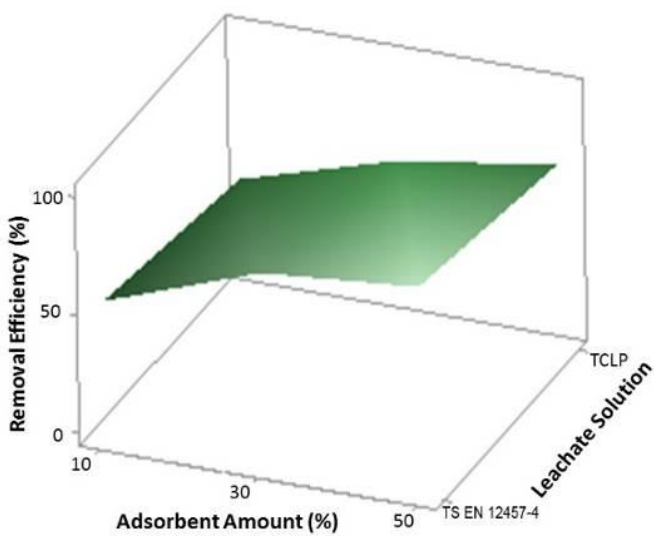

(f)

Figure 8. Surface plots for lead removal from lead smelting slag 


\section{Acknowledgments}

This project was supported by Ondokuz Mayıs University with the project number PYO.MUH.1904.13.008

\section{References}

Al-Abed S.R., Hagemen P.L., Jegadeesan G., Madhavan N. and Allen D. (2006), Comparative evaluation of short-term leach tests for heavy metal release from mineral processing waste, Science of The Total Environment, 3, 14-23.

Ai M., Yang G. and Zhang R., (2006), Minimum aberration blocking of regular mixed factorial designs, Journal of Statistical Planning and Inference, 136, 1493-1511.

Araç E. (2014), Adsorption of Lead and Copper lons from Aqueous Solutions onto Sepiolite, İstanbul Technical University, Institute of Science and Technology.

Cohen B. and Petrie J.G. (2005), The application of batch extraction tests for the characterisation of solidified ferro alloy waste products, Journal of Environment Management, 76, 221-229.

Coz A., Andres A., Soriano S., Viguri J.R., Ruiz M.C. and Irabien J.A. (2009), Influence of commercial and residual sorbents and silicates as additives on the stabilisation/solidification of organic and inorganic industrial waste, Journal of Hazardous Materials, 164(2-3), 755-761.

Craggs R., Cooke J., Mathieson T. and Park J. (2006), Potential of Mussel Shell as a Biosorbent for Stormwater Treatment, Hamilton.

Çoruh S. and Geyikçi F. (2012), Adsorption of Copper (II) lons on Montmorillonite and Sepiolite Clays: Equilibrium and Kinetic Studies, Desalination and Water Treatment, 45(1-3), 351-360.

Demotica J.S., Amparado R.F., Malaluan R.M. and Demayo C.G. (2012), Characterization and leaching assessment of ferronickel slag from a smelting plant in Iligan City, Philippiness, International Journal of Environmental Science and Development, 3(5), 470-474.

Djukić A., Jovanović U., Tuvić T., Andrić V., Novaković G.J., Ivanović N. and Matović L. (2013), The potential of ball-milled Serbian natural clay for removal of heavy metal contaminants from wastewaters: Simultaneous sorption of $\mathrm{Ni}, \mathrm{Cr}, \mathrm{Cd}$ and $\mathrm{Pb}$ ions, Ceramics International, 39, 7173-7178.

Du Y., Lian F. and Zhu L., (2011), Biosorption of divalent Pb, Cd and $\mathrm{Zn}$ on aragonite and calcite mollusk shells, Environmental Pollution, 159, 1763-1768.

EPA US., (1992), Method 1311: Toxicity Characteristic Leaching Procedure (TCLP)', in Test Methods for Evaluating Solid Waste: Physical /Chemical Methods; In: Agency EP, Editor. Washington DC.

Erbaş O. and Semra O.H., (2006), Deney Düzenleri ve İstatistik Analizleri, Gazi Kitabevi, Ankara.

Eren E. and Gumus H. (2011), Characterization of the structural properties and $\mathrm{Pb}(\mathrm{II})$ adsorption behavior of iron oxide coated sepiolite, Desalination, 273, 276-284.

European Waste Catalogue (EWC), (2000).

Filiz E., (2007), Removal of Heavy Metals from Water with Organic Based Natural Adsorbents, İstanbul Technical University, Institute of Science and Technology.

Ghasemi N., Tamri P., Khademi A., Nezhad N.S. and Alwi S.R.W. (2013), Linearized Equations of Pseudo Second-order Kinetic for the Adsorption of $\mathrm{Pb}$ (II) on Pistacia Atlantica Shells, IERI Procedia, 5, 232-237.
Güneren E., (2010), Adsorption of Lead and Copper lons from Aqueous Solutions by Bentonite, İstanbul Technical University, Institute of Science and Technology.

Kaksonen A.H., Särkijärvi S., Puhakka J.A., Peuraniemi E., Junnikkala S. and Tuovinen O.H. (2016), Chemical and bacterial leaching of metals from a smelter slag in acid solutions, Hydrometallurgy, 159, 46-53.

Kim S.D. and Park Y.B. (2001), Effects on the removal of Pb2+ from aqueous solution by crab shell, Journal of Chemical Technology and Biotechnology, 76, 1179-1184.

Kogbara R.B. (2014), A review of the mechanical and leaching performance of stabilized/solidified contaminated soils, Environmental Reviews, 22(1), 66-86.

Kreusch M.A., Ponte M.J.J.S., Ponte H.A., Kaminari N.M.S., Marino C.E.B. and Mymrin V., (2007), Technological improvements in automotive battery recycling, Resources, Conservation and Recycling, 52, 368-380.

Kumar S., Singh D., Mishra A.K., Upadhyay M. and Kumar S. (2014), Red mud as adsorbent to remove lead (II) from aqueous solutions, Research Journal of Recent Sciences, $\mathbf{3}$, $18-27$.

Kurt, O., (2012), Mutlu Akü ve Malzemeleri San.A.Ş.

Mining Specialization Commissions Report, (2001), DPT, Ankara.

Montgomery, D., Runger, G.., Hubele, N., (2001), Engineering Statistics. John Wiley \& Sons, New York.

Ogundiran M.B., Nugteren H.W. and Witkamp G.J. (2013), Immobilisation of lead smelting slag within spent aluminatefly ash based geopolymers, Journal of Hazardous Materials, 248-249, 29-36.

Ozdes D., Duran C. and Senturk B.H. (2011), Adsorptive removal of $\mathrm{Cd}(\mathrm{II})$ and $\mathrm{Pb}$ (II) ions from aqueous solutions by using Turkish illitic clay, Journal of Environmental Management, 92, 3082-3090.

Regulation of landfill of wastes, (2010) 27533 rd Official Gazette (Date: 26.03.2010), Turkey.

Sahu M.K., Mandal S., Dash S.S., Badhai P. and Patel R.K. (2013), Removal of $\mathrm{Pb}$ (II) from aqueous solution by acid activated red mud, Journal of Environmental Chemical Engineering, 1, 1315-1324.

Seignez N., Gauthier A., Bulteel D., Damidot D. and Potdevin J.L. (2008), Leaching of lead metallurgical slags and pollutant mobility far from equilibrium conditions, Applied Geochemistry, 23, 3699-3711.

Singh T.S. and Pant K.K. (2006), Experimental and modelling studies on fixed bed adsorption of $\mathrm{As}$ (III) ions from aqueous solution, Separation and Purification Technology, 48, 288-296.

Sipos P., Németh T., Kis V.K. and Mohai I. (2008), Sorption of copper, zinc and lead on soil mineral phases, Chemosphere, 73, 461-469.

Smaniotto A., Antunes A., Filho I. do N., Venquiaruto L.D., de Oliveira D., Mossi A., Di Luccio M., Treichel H. and Dallago R. (2009), Qualitative lead extraction from recycled lead-acid batteries slag, Journal of Hazardous Materials, 172, $1677-1680$

Special waste statistics (2003-2009), (2011), Ministry of environment and forestry, General directorate for environmental management, Ankara.

Şenoğlu B. and Acitaş Ş. (2014), Statistical Experimental Design Constant Effective Models, Nobel, Ankara. 
Tripathi A. and Ranjan M.R. (2015), Heavy Metal Removal from Wastewater Using Low Cost Adsorbents, Journal of Bioremediation and Biodegradation, 6(6), 1-5.

Vaclavikova M., Misaelides P., Gallios G., Jakabsky S. and Hredzak S. (2005), Removal of cadmium, zinc, copper and lead by red mud, an iron oxides containing hydrometallurgical waste, Studies in Surface Science and Catalysis, 155, 517-525.

Vest H. and Jantsch F., (1999), Environmental Sound Battery Disposal and Recycling, Environmental Handbook, German Ministry for EconomicCooperation and Development.

Wu Q., Chen J., Clark M. and Yu Y. (2014), Adsorption of copper to different biogenic oyster shell structures, Applied Surface Science, 311, 264-272.

Yadav S. and Yadav S. (2014), Investigations of metal leaching from mobile phone parts using TCLP and WET methods, Journal of Environmental Management, 144, 101-107.

Yin Y. and Zhou J. (2015), Minimax design criterion for fractional factorial designs, Annals of the Institute of Statistical Mathematics, 67, 673-685.

Yu J., Qiao Y., Sun L., Jin L., Wang W. and Ma C. (2015), Detoxification of ashes from a fluidized bed waste incinerator, Chemosphere, 134, 346-354.

Zhao S. and Chen X. (2012a), Mixed two-and four-level fractional factorial split-plot designs with clear effects, Journal of Statistical Planning and Inference, 142, 1789-1793.

Zhao S. and Chen X., (2012b), Mixed-level fractional factorial splitplot designs containing clear effects, Metrika, 75, 953-962. 